\title{
Turizm Sektöründe Aile İşletmelerinin Kurumsallaşma Sorunları: Kocaeli Örneği
}

\section{Özet}

\author{
Gülçin ÖZBAYa, b, Koray Yunus Ellidörtc
}

Anahtar Kelimeler

Aile ișletmesi

Kurumsallaşma

Kurumsallaşma Sorunları

Makale Hakkında

Geliş Tarihi: 10.11.2019

Kabul Tarihi: 05.08.2020

Doi: 10.18026/cbayarsos.644869 alan yöneticilerin fevri kararlar alması, işletmeyi ilgilendiren stratejik kararların işletme sahibi tarafından verilmesi, aile bireylerinin aldığ sözlü olarak iletmesi, aile dışından olan yöneticilerin kararlarda etkisinin olmaması, aile bireylerinin farklı görüşleri nedeniyle kararların uygulanmasında zorluklar yaşanması ve aile bireyleri tarafından alınan kararların akrabalık bağı olmayan yönetici ve çalışanlara hızlı bir şekilde bildirilmemesi şeklinde sıralanabilir.

\section{The Institutionalization Problems of Family Businesses In The Tourism Sector: The Case of Kocaeli}

\begin{abstract}
Family businesses take an important place in the labor-intensive tourism sector as well as in all sectors. In this context, the behavior of family members in the business and the prevailing managerial approach should be examined. The aim of the research is to identify the institutionalization problems of family businesses operating in the tourism sector. Semi-structured interviews were held with the managers of family businesses operating in the tourism sector in Kocaeli and descriptive analysis was carried out. In interviews with a total of 25 participants, it is stated that more than half of the businesses do not have a institutional identity. According to the results of the research, institutionalization problems of family businesses serving in tourism sector can be listed as; making impulsive decisions by executives who take the position of senior management in the business, making strategic decisions concerning the business by the business owner, verbal communication of decisions taken by family members, non-family managers have no influence on decisions, difficulties in implementing decisions due to different views of family members, not being able to quickly report decisions made by family members to unrelated managers and employees.
\end{abstract}

Keywords

Family Business

Institutionalization

Institutionalization Problems

About Article

Received: 10.11 .2019

Accepted: 05.08.2020

Doi: $10.18026 /$ cbayarsos.644869

a İletişim Yazarı: gozbay@subu.edu.tr

b Dr.Öğr.Üyesi, Sakarya Uygulamalı Bilimler Üniversitesi, Turizm Fakültesi / ORCID ID: orcid.org/0000-0002-5647-7137

c Yüksek Lisans Öğrencisi, Sakarya Uygulamalı Bilimler Üniversitesi, Turizm Fakültesi / ORCID ID: orcid.org/0000-0002-7803-7562 


\section{Giriş}

Artan rekabet ve değişen ekonomik koşullar tüm işletmeleri olduğu gibi aile işletmelerini de etkilemekte ve aile işletmeleri yaşanan bu gelişmelere karşı savunma mekanizması olarak yönetim biçimini değiştirerek kurumsallaşmaya yönelmektedir. Aile işletmelerinde kurumsallaşma kavramı daha önemli bir hal almaktadır. Türkiye ekonomisinde bulunan işletmelerin ortalama \%95'ini aile işletmeleri oluşturmaktadır (PwC, 2012).

Ürün ve hizmet alanlarında faaliyet gösteren işletmelerin çoğunluğu aile işletmelerinden oluşmaktadır. Dünyadaki işletmelerin \%65-80'inin aile işletmesi olduğu tespit edilmiştir (Goto, 2014: 78). Büyük aile işletmelerine Ford, Hermes, H\&M, Michelin ve Bata örnek gösterilebilir. Türkiye'de aile işletmelerinin GSMH'daki payı \%75'in üstünde olduğu bilinmekte (Elalmış, 2011: 1-2) ve Sabanc1, Koç ve Doğuş gibi birçok büyük aile işletmesi bulunmaktadır (Kırım, 2003: 3). Türkiye'de turizm sektöründe ise Dedeman, Hilton ve Anemon gibi büyük aile işletmeleri faaliyet göstermektedir. Turizm sektörü, bacasız sanayi olarak anılmaktadır. Gelişmekte olan ülkeler için ekonomik olarak olumlu yönde etki etmekte, sıcak para ve döviz girişini sağlayan turizm sektörü ülkenin ihracat açığını kapatmada kurtarıcı bir sektör olarak değerlendirilmektedir (Terzi ve Pata, 2016: 46). Turizmin çarpan etkisi nedeniyle turistlerin otel dışında yapmış olduğu harcamalar da diğer sektörlere gelir kaynağı olmaktadır (Kar ve diğerleri, 2004: 90). Bunun yanı sıra sektörün dolaylı yoldan diğer sektörlere istihdam yaratması turizm sektörünün öneminin artmasına neden olmaktadır. Bu denli öneme sahip turizm sektöründe yer alan aile işletmelerinin yapısal olarak analiz edilmesi, kurum kültürleriyle ilgili araştırma yapılması gerekmektedir.

Turizm sektörünün ülke ekonomisine katkısı yüksek seviyededir. 2018 turizm verilerine bakıldığında 29.512.926 \$ gelir elde edilmiştir (TUİK 2018). Ülkeye bu derecede katkı sağlayan bir sektör olan turizm sektöründe aile işletmelerinin kurumsallaşmaya bakış açıları ciddi bir önem arz etmektedir. Çalışmada, aile işletmesi kavramı, aile işletmesinin önemi ve özellikleri, kurumsallaşma kavramı, kurumsallaşma kavramının aile işletmeleri açısından önemi teorik olarak ele alınmaktadır. Ayrıca aile işletmelerinin sürdürülebilirliğinde etkili olan kurumsallaşmaya işletmelerin bakış açları ve bu kapsamda yaşanan sorunlar belirlenmeye çalışılmıştır.

\section{Kavramsal Çerçeve}

\section{Aile İşletmesi Kavramı}

Aile işletmesi kavramı işletmelerin kuruluş şekli, ailenin kültürel yapısı ve işletmenin faaliyet gösterdiği sektöre göre farklılık göstermektedir (Fındıkçı, 2008: 16). Kuruluş amacı; işletmeyi yöneten, geliştiren, büyüten ve işletmenin sahibi olan ailenin geçimini sağlamak olan ve var olan mirası kendi aralarında paylaşmasını sağlayan, kararların alınmasında büyük ölçüde aile üyelerinin etkili olduğu ve aileden en az iki kuşağın işletmede istihdam edildiği işletmeler aile işletmeleri olarak tanımlanmaktadır (Karpuzoğlu, 2000:18).

İşletmenin aile işletmesi sayılabilmesi için bir aileden iki veya daha fazla aile bireyinin aynı işletmeyi yönetmesi, çalışması veya işletmenin çoğunluk hissedarı olması gerekmektedir. Tek bir kişinin sahip olduğu aileden başka bir kişinin işletmede çalışmadığ 1 işletmeler patron işletmeler olarak nitelendirilmekte ve bu işletmeler genelde ikinci nesle geçerken aile işletmesi kategorisinde değerlendirilmektedir (Baykal, 2004: 85). Bu bağlamda; bir ailenin en az iki nesliyle yakından özdeşleşen ve bu bă̆ın şirket politikası, ailenin çıkarları ve amaçları üzerinde karşılıkl etkisi olduğu işletmeler aile işletmeleridir (Donnelley, 1964: 94; Yolaç ve Doğan, 2011: 84-85). Aile 
işletmesinin tanımlanmasında esas alınacak kriterleri aşağıdaki gibi sıralanabilir (Barnes ve Hershon, 1976: 106; Shanker ve Astrachan,1996: 108; Çemberci, 2013: 3):

a. Şirketin mülkiyetinin aileye ait olma oranı

b. Şirketin mevcut yönetiminin ailenin elinde bulunması

c. Oy kontrolü

d. Şirketin kurucu veya kurucularının aile üyelerinden olması ve

e. Farklı jenerasyonların aktif olarak yönetimde yer alması

Aile işletmelerindeki önemli pozisyonlar aile bireylerine verilmektedir. Muhasebe, finansman, satın alma, pazarlama gibi departmanlarda dışarıdan bir kişi çalışsa dahi aile bireylerinin kontrolü altında görev yapmaktadır. Bu departmanlarda yönetici konumunda olan aile bireyleri ise kendi bilgi, tecrübe ve kişilik özelliklerine bakılmaksızın departmanlara yerleştirilmektedir (Miller ve diğerleri, 2003: 513; Yazıcıoğlu ve Koç, 2009: 499). Genellikle işletmenin başında bulunan kişi ise ailenin reisi veya ailede baskın olan kişi olmaktadır.

Toplumun yapı taşı olan ailenin bireyleri ailesini korumak istemekte ve aile işletmesi de tıpkı bu durumu yansıtmaktadır. Aile işletmeleri çocuklarına fırsat yaratmak, aile mirasının devamını sağlamak, aileyi bir arada tutmak, kendine bağlı çalışanları korumak ve aileye finans kaynağ1 yaratmak amaciyla kurulmaktadır (Vera ve Dean, 2005: 321; Ward, 1987: 145; Özkaya ve Şengül, 2006: 110). Aile bireylerinin birinin veya bir kaçının yaşadığ 1 çevredeki dost ve akrabalarının başarılı bir işletme kurması, aile bireylerini olumlu yönde etkileyerek işletme açmaya teşvik etmektedir. Ayrıca aile bireylerinin çalıştığı işlerde karşılaştıkları olumsuzluklar da kendi işletmesini açmasına sebep olmaktadır. Aileyi veya kişileri bir işletme kurmaya teşvik eden diğer sebep ise, kendi işinin patronu olma, başkalarına yöneticilik yapma ve aile içinden olan kişilerin geleceğini güvence alma isteğidir (Akça, 2010: 20)

\section{Kurumsallaşma Kavramı ve Aile İşletmelerinde Kurumsallaşma}

İşletmedeki süreçlerin sistem haline gelmesi kurumsallaşma olarak ifade edilmektedir (Akça, 2010: 47). Kurumsallaşma; bir işletmenin, faaliyetlerini kişilerin varlığına bağımlı olmadan sürdürebilmesini ve geliştirebilmesini sağlayan bir yapının kurulmasıdır. Böylece kurumsallaşma işletmeyi kişilere bağımlı olmaktan büyük ölçüde kurtarmaktadır ve herhangi bir sebeple işletmede, özellikle de kilit noktalarda, görev alan kişilerin işten uzaklaşmaları durumunda işletmenin en az miktarda zarar görmesini sağlamaktadır (Akça, 2010: 48; Yıldız, 2008: 89). Bir başka tanımlamada, işletmenin o günün getirmiş olduğu koşullara ayak uyduracak gerekli yönetim ve örgüt sistemini yaratarak ihtiyacı karşılaması, kurum olmanın gereklilikleri olan uygun davranışları, işletme standartlarını ve ilkelerini belirleyerek bunları yazılı hale getirmesi ve uygulaması kurumsallaşma olarak aktarılmaktadır (Aydemir ve diğerleri, 2004: 608).

Dünyadaki sosyo-ekonomik değişim ve gelişimler işletmeleri yeni strateji ve politikalar üretmeye zorlamıştır. İşletmeler gerek rekabet üstünlügü gerekse varlığını sürdürebilmek için kurumsallaşma yoluna gitmiştir (Gülen, 2005: 21). Kurumsallaşma değişimi getirmektedir. Kurumsallaşma sürecinde işletmeler yapısal özelliklerini değiştirmeli, özellikle örgüt yapısında ve sisteminde çevreye uygun olacak şekilde düzenleme yapmalıdır. Bu değişimi gerçekleştirmede en büyük sorumluluk ise yönetim kademesine düşmektedir (Akyol ve Zengin, 2014: 7). Kurumsallaşmanın en önemli nedenlerinden bir diğeri ise rekabet avantajıdır. Günümüzde rekabet ortamı oldukça sert geçmekte bu durumda kurumsallaşmanın önemini arttırmaktadır (Doğan, 1998: 145). 
Aile işletmelerinin kurumsallaşamaması; finansal yapı, rekabet koşulları, birinci kuşağın geleneklerine bağlı kalması gibi bir çok nedene dayanmaktadır (Aksoy ve Çabuk, 2006: 48). Geleneklerine bağlı kalan aile işletmesinin patronu yani ailede en çok sözü geçen kişi, geçmişte pazardaki boşluğu keşfederek işletmeyi kurmuştur. Tek kişinin vizyonu, enerjisi, yeterliliği, esnekliği ve şansına bağlı olarak ilerleyen işletmelerde bu kişiye gelen herhangi bir zarardan direkt olarak işletme etkilenmektedir (Akça, 2010: 31). İşletmedeki iş konumlarına uzman olan kişilerin yerine işi sahada öğrenen aile bireylerinin yerleştirilmesinden dolayı iş süreçlerinde teknik uzmanlık eksikliğinden dolayı sorunlar yaşanmaktadır (Saral Kobal ve Aşkun Yıldırım, 2016: 102). Aile işletmelerinde sermayenin aileye ait olması sebebiyle uzun süreli finans eksikliği kurumsallaşmanın önünde ciddi bir engel teşkil etmektedir (Aksoy ve Çabuk, 2006: 48).

Aile işletmeleri büyümeye başladığında işletmeyi kuran aile büyüğünün bilgisi ve tecrübesiyle bir yere kadar ilerleyebilirler fakat bu büyümenin getirdiği sorunlar yaşanmaktadır. Bu sorunları çözmek için aile işletmesinin hızlı değişimlere ayak uydurması gerekmektedir. Aile işletmeleri kurucuya bağllıklarından dolayı bu değişimlere yavaş tepki vermektedir (Günver, 2002: 45). Günümüz ekonomik koşullarında işletmelerin ayakta durması gittikçe zorlaşmaktadır. İşletmeler yaşamlarını sürdürebilmek için dinamik ve değişime açık şekilde hareket etmektedir. Aile işletmesinin kurucusu, işletmenin ilk yıllarında risk alarak işletmeyi belirli bir büyüklüğe ulaştırmıştır ancak zaman geçtikçe risk almak yerine tutucu davranışlar sergilemektedir. Bu tutucu davranışlar işletmenin hızlı ve sürekli büyümesini engellemektedir. Aile bireylerinin yerine profesyonel yöneticilerin daha çok risk alarak ve fırsatları değerlendirerek hızlı ve sürekli büyüme hedeflerini gerçekleştirmede daha etkili oldukları görülmektedir (Günel, 2005: 32-33; Kömeçoğlu, 2009: 20).

Aile işletmelerinin yaşamlarını sürdürebilmesi ve nesilden nesile aktarılması için en etkili yol kurumsallaşmadır (Alkara ve Kiracı, 2009: 174). Kurumsallaşma başta aile işletmelerine gerekli gelmese de işletme büyüdükçe aile bireylerinin işlere yetişememesi ve kontrolü kaybetmesi kurumsallaşmayı işletme için gerekli bir hale gelmektedir. Fakat işletme sahibi olan ailenin, yönetimde ve işletmede güç kaybetme korkusu profesyonel yöneticilere, sistemsel işleyişe ve kurumsallaşmaya soğuk bakmalarına neden olmaktadır (Bayer, 2005: 130131). İşletme yönetiminin aile bireylerinde olmasının başlıca sorunlarından biri karar mekanizmasının aile bireylerinde olmasıdır. Aile bireylerinde olan karar yetkisi planlamalarda sorunlara neden olabilmektedir. Yapılan planlamalar, veriler ve analizler yerine sezgilere ve tecrübelere dayanmaktadır. Bazen bu planlar şans faktörü devreye girerek başarılı olsa da sürdürülebilir şekilde başarılı olma şansı düşüktür (Sevinç, 2005: 318). Yönetimsel açıdan yetersiz kalan aile bireyleri SWOT analizi yapma, vizyon ve misyon oluşturma, politika ve strateji geliştirmede yetersiz kalmaktadır. Uzun vadeli kararlar yerine orta ve kısa vadeli kararlar almakta ve bu kararlara aile dışı yöneticileri katmadıklarından dolayı profesyonel anlamda planlama yapamamaktadır (Tekin, 2004:127).

Kurumsallaşamayan aile işletmelerinde bir diğer sorun ise koordinasyon sorunlarıdır ve bu sorunlar yönetimi de etkilemektedir. İşletmede çalışan aile üyeleriyle aile dışı çalışanlar arasında çoğu zaman çatışma yaşanmaktadır. Aile üyelerine yapılan kayırmalar ve öncelik tanımaları aile dışı çalışanlara rahatsızlık vermekte ve bu yaşanan çatışmalar departmanlar arası sorunlara neden olmaktadır (Tanta, 2004: 84).

Aile işletmelerinde kurumsallaşma kavramı yanlış algılanmaktadır. Kurumsallaşma sadece aile bireyi olmayan kişilerin yönetimde olması değil uygun bilgi, beceri, yetenek ve 
tecrübedeki aile bireyi veya aile bireyi dışındaki kişilerin doğru konumlarda yetkilendirilmesidir (Yazıcıoğlu ve Koç, 2009: 500). Aile işletmelerinde organizasyon yapısı karmaşık bir haldedir. Kurumsallaşma kapsamında organizasyon yapısında değişiklik kaçınılmazdır. Bu değişiklikle beraber işletmede sistem ön plana çıkarak yapılan işler standart hale gelmektedir. Bir işin kim tarafından ne zaman, nerede, nasıl, hangi yetkiyle ve sorumlulukla yapılacağı belirlenerek örgüt yapısı net bir şekilde oluşturulmalıdır (Yazıcıoğlu ve Koç, 2009: 501).

\section{Yöntem}

$\mathrm{Bu}$ araştırmanın amacı turizm sektöründe faaliyet gösteren aile işletmelerinin kurumsallaşma kavramına bakış açılarının ve kurumsallaşmaya ilişkin yaşadıkları sorunların belirlenmesidir. Çalışmanın tasarlanmasında nitel araştırma yöntemlerinden betimsel analiz kullanılmıştır. Verilerin elde edilmesinde yarı yapılandırılmış görüşme tekniği tercih edilmiş olup, görüşme sorularının oluşturulmasında alanyazın taraması sonucunda elde edilen bilgiler temel alınmıştır. Ayrıca aile işletmesi çalışanları ve yöneticileriyle yapılan ön görüşme sonucunda belirlenen konular da dikkate alınarak 21 sorudan oluşan bir mülakat formu hazırlanmıştır. Ölçeğin yapı geçerliliğinin tespit edilebilmesi amacıyla uzman/akademisyen görüşleri de alınmıştır.

Çalışma, Kocaeli'de bulunan ve turizm sektöründe faaliyet gösteren aile işletmelerinde gerçekleştirilmiştir. Araştırmada amaçlı örnekleme yöntemi kullanılarak, araştırmanın konusunu oluşturan kişi, işletme ve durum hakkında ayrıntılı bilgi toplanması hedeflenmiştir (Maxwell, 1992: 283; Özdemir, 2010: 327). Bu doğrultuda çalışmada; daha çok sektör tecrübesi olan ve çalışma hayatını aile işletmelerinde geçiren üst kademe yöneticilerden veri toplanmıştır. Bu kriterlere uygun toplam 39 yönetici ile görüşme yapılmıştır.

Araştırma yapılırken bir çok zorluk ile karşılaşılmıştır. Sorunlardan en büyüğü araştırma yapılan işletmelerde katılımcıların çekimser ve eksik yanıt vermesi olmuştur. 14 katılımcıya ilişkin görüşme formu kayıt dışı tutulmuştur. Araştırma yapılırken ilginç bir olay yaşanmış olup bir işletmede üst düzey aile dışı yönetici ile görüşmede katılımcı, araştırmacının işletme sahibi tarafından görevlendirildiğini, araştırma adı altında işletme sahipleri hakkında düşüncelerinin alınmaya çalışıldığını belirtmiş ve görüşmeden çekilmiştir. Geri kalan 25 katılımcı soruları eksiksiz yanıtlamış olup değerlendirmeye alınmıştır.

Katılımcıların; cinsiyet, medeni durum, toplam deneyim süresi, eğitim durumu, organizasyon yapısındaki konumu, işletmede çalışma süresi, işletme sahipleriyle akrabalık durumuna ilişkin sorular yönlendirilmiştir. İşletme kapasitesi, işletme türü, işletme belge türü, işletmenin açı kalma süresi, işletmeyi işleten nesil, işletmenin doluluk oranı, çalışan sayısı, işletmenin hizmet süresi, işletmenin sahiplik türü gibi bilgiler araştırma kapsamında değerlendirilmeye alınmıştır. Çalışma kapsamında yanıt aranan ana araştırma sorusu, turizm sektöründe faaliyet gösteren aile işletmelerinin kurumsallaşma sorunlarının neler olduğudur. Bu sorunları belirlemek üzere yanıt aranan diğer araştırma soruları ise aşağıda sıralanmaktadır.

a. Aile işletmelerinde kurumsallaşma kavramına bakış açısı nasıldır?

b. Yöneticiler çalıştıkları aile işletmelerinin kurumsal kimliğe sahip olduğunu düşünmekte midir?

c. Aile işletmelerinde çalışanlar ile aile üyeleri arasında ilişki nasıl şekillenmektedir? 
d. Aile işletmelerindeki karar ve planlarda kurumsallaşmaya ilişkin genel durum nasıldır? Nasıl bir işleyiş söz konusudur?

\section{Bulgular}

Araştırmaya katılan katılımcıların \%72'si erkek, \%28'i kadınlardan oluşmaktadır. Tablo 1.'de katılımcılara ilişkin özellikler yer almaktadır. Bu katılımcıların \%64'ü evlidir. Katılımcıların çoğunluğu (\%40) 41 yaş üstü ve \%48'i en az lisans mezunudur. Katılımcıların tamamı yönetici olup; \%20'si satış bölümünde, \%20'si mutfakta ve \%20'si ön büroda yönetici olarak çalışmaktadır. Katılımcıların \%8'i genel müdür, \%16'sı genel müdür yardımcısı ve \%16'sı yiyecek içecek müdürü pozisyonundadır.

Tablo 1. Katılımcılara İlişkin Özellikler

\begin{tabular}{|c|c|c|c|}
\hline Demografik Özellik & Kategori & $\mathbf{N}$ & $\%$ \\
\hline \multirow[t]{2}{*}{ Cinsiyet } & Erkek & 18 & 72 \\
\hline & Kadın & 7 & 28 \\
\hline \multirow[t]{4}{*}{ Yaş } & 30 ve alt1 & 3 & 12 \\
\hline & $31-35$ & 6 & 24 \\
\hline & $36-40$ & 6 & 24 \\
\hline & 41 ve üstü & 10 & 40 \\
\hline \multirow[t]{2}{*}{ Medeni Durum } & Evli & 16 & 64 \\
\hline & Bekar & 9 & 36 \\
\hline \multirow[t]{4}{*}{ Eğitim Seviyesi } & Lise & 5 & 20 \\
\hline & Ön lisans & 7 & 28 \\
\hline & Lisans & 12 & 48 \\
\hline & Yüksek lisans & 1 & 4 \\
\hline \multirow[t]{4}{*}{ Toplam Deneyim Süresi } & 1 yıldan az & 1 & 4 \\
\hline & $1-5$ yıl & 6 & 24 \\
\hline & $6-10$ yıl & 7 & 28 \\
\hline & 11 yıl ve üzeri & 11 & 44 \\
\hline \multirow[t]{4}{*}{ İşletmedeki Çalışma Süresi } & 1 yıldan az & 6 & 24 \\
\hline & $1-5$ yıl & 12 & 48 \\
\hline & $6-10$ y1l & 5 & 20 \\
\hline & 11 yıl ve üzeri & 2 & 8 \\
\hline \multirow[t]{6}{*}{$\begin{array}{l}\text { Organizasyon Yapısındaki } \\
\text { Pozisyonu }\end{array}$} & $\begin{array}{l}\text { Satış bölümü } \\
\text { yöneticisi }\end{array}$ & 5 & 20 \\
\hline & Mutfak yöneticisi & 5 & 20 \\
\hline & Ön büro müdürü & 5 & 20 \\
\hline & Genel müdür & 2 & 8 \\
\hline & $\begin{array}{l}\text { Genel müdür } \\
\text { yardımcısı }\end{array}$ & 4 & 16 \\
\hline & F\&B müdürü & 4 & 16 \\
\hline \multirow[t]{2}{*}{ İşletme Sahibiyle Akrabalık Durumu } & Akraba & 4 & 16 \\
\hline & Akraba değil & 21 & 84 \\
\hline
\end{tabular}

Katılımcıların \%84'ünün işletme sahipleriyle akrabalık bağı bulunmamaktadır. Katılımcıların \%72'si 6 yıl ve üzeri deneyim süresine sahiptir. Görüşülen katılımcıların çoğunluğu (\%48) 1-5 yıl arası süredir şu anki işletmede çalışmakta olduğunu belirtmektedir. Görüşme yapılan 
katılımcıların bulunduğu işletmelerin tamamı Bakanlık belgeli işletmeler olup, katılımcıların \%64' ü yiyecek içecek işletmesinde çalışmaktadır.

Tablo 2. İşletmelere İlişkin Özellikler

\begin{tabular}{|c|c|c|c|}
\hline Özellik & Kategori & $\mathbf{N}$ & $\%$ \\
\hline \multirow{6}{*}{ İşletme Kapasitesi } & 20 kişiden az & 5 & 20 \\
\hline & $21-40$ & 1 & 4 \\
\hline & $61-60$ & 2 & 8 \\
\hline & $61-80$ & 1 & 4 \\
\hline & $81-100$ & 0 & 0 \\
\hline & 101 ve üzeri & 16 & 64 \\
\hline \multirow{2}{*}{ İşletmenin Açık Kalma Süresi } & 13-17 Saat & 11 & 44 \\
\hline & 18-24 Saat & 14 & 56 \\
\hline \multirow{4}{*}{ Doluluk Oranı } & $\% 31-50$ & 5 & 20 \\
\hline & $\% 51-70$ & 16 & 64 \\
\hline & $\% 71-90$ & 3 & 12 \\
\hline & $\% 91-100$ & 1 & 4 \\
\hline \multirow{3}{*}{ Çalışan Sayısı } & 20 kişiden az & 21 & 84 \\
\hline & $21-40$ & 3 & 12 \\
\hline & $41-60$ & 1 & 4 \\
\hline \multirow{4}{*}{ Hizmet Süresi } & 1 yıldan az & 1 & 4 \\
\hline & $1-5$ y1l & 4 & 16 \\
\hline & $6-10$ yil & 3 & 12 \\
\hline & 11 yıl ve üzeri & 17 & 68 \\
\hline \multirow{3}{*}{ İşletmeyi İşleten Nesil } & 1. Nesil & 4 & 16 \\
\hline & 2. Nesil & 19 & 76 \\
\hline & 3. Nesil & 2 & 8 \\
\hline
\end{tabular}

Görüşme yapılan aile işletmelerinin \%64'ü büyük ölçekli işletme kategorisinde yer almakta olup, \%51-70 arası doluluk oranına sahiptir. Buna karşın işletmelerin \%84'ünün 20 kişiden az çalışan istihdam ettiği Tablo 2.'de görülmektedir. İşletmelerin yarıya yakını 13-17 saat arası hizmet verirken, kalan kısmı 18-24 saat açıktır. İşletmelerin \%68'i 11 yıl ve üzeri süredir hizmet vermekte olup \%76'sı 2. Nesil tarafından işletilmektedir.

\section{Turizm Sektöründe Aile İşletmelerinin Kurumsallaşma Sorunları Üzerine Elde Edilen Bulgular}

Katılımcılara araştırma konusu doğrultusunda yöneltilen 21 adet soruya verilen yanıtlar analiz edilerek ortak verilen yanıtlar çeşitli temalar kapsamında değerlendirilmiştir. Değerlendirmeye alınan katılımcıların tamamı bütün soruları eksiksiz yanıtlamıştır. Katılımcılara yöneltilen sorular üç ayrı grupta değerlendirilmiş, her soru grubu ve yanıtına ilişkin bilgiler için ayrı tablolar hazırlanmıştır. Tablolarda 'soru' başlığı altındaki sütunda katılımcılara sorulan sorular, 'yanıt' sütununda verilen cevaplara atanmış temalar, N başlığı altında ise kaç adet katılımcının belirlenen temaya cevap verdiği ve 'katılımcı' sütununda belirlenen temaya hangi katılımcının cevap verdiği örülmektedir. Katılımcılar tabloda K harfiyle belirtilmiş olup yanındaki sayı hangi katılımcı olduğunu belirtmektedir. 
Tablo 3.'te kurumsallaşma kavramının yer aldığı soru grubu ve yanıtları yer almaktadır. "Kurumsallaşma sizce ne anlama gelmektedir?" sorusuna verilen yantlara göre; katılımcıların kurumsallaşmayı sistem, kararlar, orta ve uzun vadeli planlar, işgören çalışma düzeni ve organizasyon şeması olmak üzere beş farklı açıdan değerlendirdiği dikkat çekmektedir. Katılımcıların \%60'ı kurumsallaşmayı işletmede alınan kararları temel alarak açıklamaktadır. Bu tanımlamanın içinde orta ve uzun vadedeki planlar da yer almaktadır.

Tablo 3. Kurumsallaşma Kavramına İlişkin Bulgular

\begin{tabular}{|c|c|c|c|}
\hline Soru & Yanit & $\mathbf{N}$ & Katılımcı \\
\hline \multirow{5}{*}{$\begin{array}{l}\text { Kurumsallaşma sizce } \\
\text { ne anlama } \\
\text { gelmektedir? }\end{array}$} & $\begin{array}{l}\text { Çalışma saatinin standart olması, } \\
\text { tatil günlerinin belli olması, } \\
\text { bütün yasal izin haklarından } \\
\text { yararlanma }\end{array}$ & 5 & K1-K2-K3-K9-K16 \\
\hline & $\begin{array}{l}\text { İşletme için alınan kısa, orta ve } \\
\text { uzun vadedeki planlara sadece } \\
\text { işletme sahipleri değil aile dışı } \\
\text { çalışan yöneticilerin de dahil } \\
\text { edilmesi }\end{array}$ & 7 & $\begin{array}{l}\text { K7-K8-K10-K12-K15- } \\
\text { K19-K20 }\end{array}$ \\
\hline & $\begin{array}{l}\text { Kararların sadece patron } \\
\text { tarafından alınmaması, bir } \\
\text { yönetim kurulunun olması }\end{array}$ & 8 & $\begin{array}{l}\text { K11-K17-K18-K21-K22- } \\
\text { K23-K24-K25 }\end{array}$ \\
\hline & $\begin{array}{l}\text { İşleyişin kişilere değil sisteme } \\
\text { bağ lı olması }\end{array}$ & 2 & K5-K6 \\
\hline & $\begin{array}{l}\text { İşletmenin organizasyon } \\
\text { yapısının tam olması, } \\
\text { departmanlara ayrılması, } \\
\text { departman sorumlularının belirli } \\
\text { olması }\end{array}$ & 3 & K4-K13-K14 \\
\hline \multirow{5}{*}{$\begin{array}{l}\text { İşletmenizin kurumsal } \\
\text { bir kimliğe sahip } \\
\text { olduğunu düşünüyor } \\
\text { musunuz? }\end{array}$} & Orta düzeyde kurumsal ve tam & & K2-K3-K10-K11-K12- \\
\hline & $\begin{array}{l}\text { kurumsallaşma için adımlar } \\
\text { atılıyor. }\end{array}$ & 11 & $\begin{array}{l}\text { K13-K16-K19-K20-K21- } \\
\text { K22 }\end{array}$ \\
\hline & Kurumsal değil. & 6 & $\begin{array}{l}\text { K4-K8-K14-K23-K24- } \\
\text { K25 }\end{array}$ \\
\hline & $\begin{array}{l}\text { Kurumsal değil ama } \\
\text { kurumsallaşma adımları atılıyor. }\end{array}$ & 6 & K1-K5-K6-K7-K9-K15 \\
\hline & $\begin{array}{l}\text { Kurumsal değil ve kurumsallığa } \\
\text { sicak bakılmiyor. }\end{array}$ & 2 & K17-K18 \\
\hline \multirow{3}{*}{$\begin{array}{l}\text { Aile dışı çalışanların } \\
\text { ve yöneticilerin } \\
\text { kurumsallaşmaya } \\
\text { karşı tutumu nedir? }\end{array}$} & $\begin{array}{l}\text { Kurumsallaşmaya sıcak } \\
\text { bakılmiyor. }\end{array}$ & 2 & K17-K18 \\
\hline & Kurumsallaşmaya sıcak bakılıyor. & 16 & $\begin{array}{l}\text { K1-K2-K3-K5-K6-K9- } \\
\text { K10-K12-K13-K14-K15- } \\
\text { K16-K19-K20-K21-K22 }\end{array}$ \\
\hline & $\begin{array}{l}\text { Kurumsallaşmanın kesinlikle } \\
\text { olmasını düşünüyorlar. }\end{array}$ & 7 & $\begin{array}{l}\text { K4-K7-K8-K11-K23- } \\
\text { K24-K25 }\end{array}$ \\
\hline
\end{tabular}


“İşletmenizin kurumsal bir kimliğe sahip olduğunu düşünüyor musunuz?" sorusuna katılımcıların \%44'ü işletmelerinin orta düzeyde kurumsal olduğunu, tam kurumsallaşma için adımlar atıldığını aktarmıştır. Katılımcıların \%8'i çalıştığı işletmenin kurumsal olmadığını ve kurumsallaşmaya sıcak bakılmadığını belirtmiştir. Katılımcıların \%24'ü ise çalıştığ işletmelerinin kurumsal olmadığını düşünmektedir. K4 kodu verilen, genel müdür yardımcısı pozisyonundaki işletme sahibiyle birinci dereceden akrabalık bağı olan katılımcl;

"İşletmemizin 6 şubesi olmasına rağmen kurumsal değiliz. Kurumsal olmamı için çok çaba verdim fakat babam (İşletme sahibi) kurumsallığın müşteriler ile bağlantımızı azaltacă̆ını, akrabalık bağ olmayan yöneticilerin kendisi kadar işletmeyi düşünmeyeceğini, bunun da kar oranın düşüreceğini ve büyüme konusunda gerileyeceğimizi düşünmektedir. Ben ise kurumsallaşmanın bizi büyüteceğini ve bütün işlerimizin standartlaşacağını düşünmekteyim. Bununla ilgili olarak kurumsallaşma danışmanı ile görüşmeler yaptım. Şuanda içinde bulunduğumuz ekonomik krizden dolayı kurumsallaşma bizim için ikinci planda kaldı." şeklinde yanıt vermiştir. İşletme sahibiyle birinci derece akrabalık bağ olmasına ve kurumsallaşma kavramına sıcak bakmasına rağmen işletmeyle ilgili karar mekanizmasında etkisinin çok düşük olduğu dikkat çekmektedir.

"Aile dışı çalışanların ve yöneticilerin kurumsallaşmaya karşı tutumu nedir?" sorusuna katılımcıların \%64'ü aile dişı çalışanların ve yöneticilerin kurumsallaşmaya sıcak baktıklarını belirtmiştir. Kurumsallaşmaya sıcak bakan katılımcıların ortak düşüncesi, kurumsallaşmanın iş yüklerini hafifleteceği, çalışma saatlerinin daha düzgün olacağı, organizasyon yapısındaki konumlarının daha net şekilde belli olacağı yönündedir. İşletme sahipleriyle akrabalık bağ1 olmayan K17 ve K18 kodlu katılımcılar yönetici ve çalışanların kurumsallaşmaya sıcak bakmadığını aktarmıştır. Bunun nedeni ise aynı katılımcılar tarafından işletmedeki aile otoritesinin kabul edildiği, aileye karşı çalışan ve yöneticilerin bağının bulunduğu şeklinde açıklanmıştır.

Çalışan ve aile üyeleri arasındaki ilişki durumuna yönelik soru grubu ve yanıtları Tablo 4.'te yer almaktadır. Katılımcların \%88'i işletmedeki aile dışı yönetici ve çalışanlara karşı tutumun ılımlı olduğunu belirtirken işletme sahibiyle akrabalık bağı olmayan \%12'lik dilim, bu çalışan ve yöneticilerin aileden biri olarak nitelendirildiğini aktarmaktadır.

"Aile içinde yaşanan sorunlar işletmeye yansıyor mu?" sorusunda katılımcıların \%60'1 aile içi yaşanan sorunların işletmeye yansımadığını belirtmiştir. Diğer katılımcılar ise aile içi sorunların işletmeye yansıdığını ve bununla birlikte iş motivasyonlarının düştügüunü dile getirmiştir. "İşletmede görevi olmayan aile üyeleri, işletme çalışanlarının işlerine müdahale ediyor mu?" şeklindeki soruya katılımcıların \%64'ü hayır cevabını vermiştir. Evet cevabını veren katılımcıların tamamı işletmede görevi olmayan aile üyelerinin gündelik işlerde işlerine müdahale ettiklerini fakat sorumluluk alanlarında işlerine müdahale etmediklerini belirtmiştir. Buna karşın aile bireyi olmayan çalışanların aile bireylerine yaklaşımlarının genellikle (\%84) sıcak ve ılımlı olduğu aktarılmaktadır. 
Tablo 4. Çalışan \& Aile Üyeleri İlişki Durumuna Yönelik Soru Grubu ve Yanıtları

\begin{tabular}{|c|c|c|c|}
\hline Soru & Yanit & $\mathbf{N}$ & Katılımcı \\
\hline \multirow[t]{2}{*}{$\begin{array}{l}\text { İşletmedeki aile dışı yönetici } \\
\text { ve çalışanlara karşı } \\
\text { tutumunuz nedir? }\end{array}$} & Ilımlı & 22 & $\begin{array}{l}\text { K2-K3-K4-K5-K7-K8- } \\
\text { K10-K11-K12-K13-K14- } \\
\text { K15-K16-K17-K18-K19- } \\
\text { K20-K21-K22-K23-K24- } \\
\text { K25 }\end{array}$ \\
\hline & $\begin{array}{l}\text { Aileden birey olarak } \\
\text { görüyorum. }\end{array}$ & 3 & K1-K6-K9 \\
\hline \multirow{2}{*}{$\begin{array}{l}\text { Aile içinde yaşanan sorunlar } \\
\text { işletmeye yansıyor mu? }\end{array}$} & Hayır & 15 & $\begin{array}{l}\text { K1-K2-K3-K6-K9-K11- } \\
\text { K12-K13-K14-K15-K19- } \\
\text { K21-K22-K23-K24 }\end{array}$ \\
\hline & Evet & 10 & $\begin{array}{l}\text { K4-K5-K7-K8-K10-K16- } \\
\text { K17-K18-K20-K25 }\end{array}$ \\
\hline \multirow{2}{*}{$\begin{array}{l}\text { İşletmede görevi olmayan } \\
\text { aile üyeleri, işletme } \\
\text { çalışanlarının işlerine } \\
\text { müdahale ediyor mu? }\end{array}$} & Evet & 8 & $\begin{array}{l}\text { K5-K6-K7-K8-K13-K14- } \\
\text { K15-K16 }\end{array}$ \\
\hline & Hayır & 17 & $\begin{array}{l}\text { K1-K2-K3-K4-K7-K9- } \\
\text { K11-K12-K17-K18-K19- } \\
\text { K20-K21-K22-K23-K24- } \\
\text { K25 }\end{array}$ \\
\hline \multirow{2}{*}{$\begin{array}{l}\text { Aile bireyi olmayan } \\
\text { çalışanların aile bireylerine } \\
\text { yaklaşımları nasıldır? } \\
\text { Çatışma yaşanıyor mu? }\end{array}$} & $\begin{array}{l}\text { Ilımlı ve sıcak ilişkiler } \\
\text { yaşanıyor. }\end{array}$ & 21 & $\begin{array}{l}\text { K1-K2-K3-K4-K5-K6- } \\
\text { K8-K9-K10-K11-K12- } \\
\text { K13-K14-K15-K19-K20- } \\
\text { K21-K22-K23-K24-K25 }\end{array}$ \\
\hline & $\begin{array}{l}\text { Genelde ılımlı fakat fikir } \\
\text { ayrılıklarından dolayı } \\
\text { çatışma yaşanıyor. }\end{array}$ & 4 & K7-K16-K17-K18 \\
\hline
\end{tabular}

İşletmedeki karar ve planlara ilişkin soru grubu ve yanıtları Tablo 5.'te yer almaktadır. "İşletmenizin orta ve uzun vadede planları var mı?" şeklinde yöneltilen soruya katılımcların \%76'sı orta ve uzun vadede plan olduğunu belirtmiştir. K4 Kodlu katılımc1: 'İşletmemizin orta vadedeki planları net şekilde bellidir. Fakat uzun vadedeki planları net şekilde belli değildir. Çünkü genelde planlarımız o günkü koşullara göre şekillenmektedir. İçinde bulunduğumuz ekonomik konjonktürden dolayı uzun vadede yeni arsalar alarak yeni şubeler açmak iken şuanda bulunduğumuz konumu korumak hedefimizdir.' şeklinde cevap vermiştir. 
Tablo 5. İşletmedeki Karar ve Planlara İlişkin Soru Grubu ve Yanıtları

\begin{tabular}{|c|c|c|c|}
\hline Soru & Yanit & $\mathbf{N}$ & Katılımcı \\
\hline \multirow{3}{*}{$\begin{array}{l}\text { İşletmenin orta ve uzun } \\
\text { vadede planları var mıdır? }\end{array}$} & Orta vadede plan var. & 2 & K3-K12 \\
\hline & $\begin{array}{l}\text { Orta ve uzun vadede } \\
\text { plan var. }\end{array}$ & 17 & $\begin{array}{l}\text { K1-K2-K4-K10-K11-K13-K14- } \\
\text { K15-K17-K18-K19-K20-K21- } \\
\text { K22-K23-K24-K25 }\end{array}$ \\
\hline & $\begin{array}{l}\text { Orta ve uzun vadede } \\
\text { plan yok. }\end{array}$ & 6 & K5-K6-K7-K8-K9-K16 \\
\hline \multirow[t]{2}{*}{$\begin{array}{l}\text { İşletmede stratejik kararları } \\
\text { kim almaktadır? }\end{array}$} & İşletme sahibi & 23 & $\begin{array}{l}\text { K1-K2-K3-K4-K5-K6-K7-K8- } \\
\text { K9-K10-K12-K14-K15-K16- } \\
\text { K17-K18-K19-K20-K21-K22- } \\
\text { K23-K24-K25 }\end{array}$ \\
\hline & Yönetim kurulu & 2 & K11-K13 \\
\hline \multirow{2}{*}{$\begin{array}{l}\text { İşletmede akraba olmayan } \\
\text { yönetici ve çalışanların } \\
\text { kararlardaki etki oranı } \\
\text { nedir? }\end{array}$} & $\begin{array}{l}\text { Genelde etki etmiyor } \\
\text { sadece fikir alınıyor. }\end{array}$ & 10 & $\begin{array}{l}\text { K10-K12-K16-K19-K20-K21- } \\
\text { K22-K23-K24-K25 }\end{array}$ \\
\hline & $\begin{array}{l}\text { Alt düzeyde etki } \\
\text { etmektedir. }\end{array}$ & 15 & $\begin{array}{l}\text { K1-K2-K3-K4-K5-K6-K7-K8- } \\
\text { K9-K11-K13-K14-K15-K17- } \\
\text { K18 }\end{array}$ \\
\hline \multirow{3}{*}{$\begin{array}{l}\text { İşletme içerisinde aldığınız } \\
\text { kararları aile bireylerindeki } \\
\text { farklı görüşlerden dolayı } \\
\text { uygulamakta zorluk çekiyor } \\
\text { musunuz? }\end{array}$} & & & K4-K5-K7-K8-K9-K10-K13- \\
\hline & Evet & 18 & $\begin{array}{l}\text { K15-K16-K17-K18-K19-K20- } \\
\text { K21-K22-K23-K24-K25 }\end{array}$ \\
\hline & Hayır & 7 & K1-K2-K3-K6-K11-K12-K14 \\
\hline $\begin{array}{l}\text { Konu hakkında gerekli } \\
\text { bilgisi ve tecrübesi }\end{array}$ & Evet & 7 & $\begin{array}{l}\text { K5-K6-K7-K8-K13-K14-K15- } \\
\text { K16 }\end{array}$ \\
\hline $\begin{array}{l}\text { bulunmayan aile bireyleri } \\
\text { tarafından kararlarınıza } \\
\text { müdahale ediliyor mu? }\end{array}$ & Hayır & 18 & $\begin{array}{l}\text { K1-K2-K3-K4-K7-K9-K11- } \\
\text { K12-K17-K18-K19-K20-K21- } \\
\text { K22-K23-K24-K25 }\end{array}$ \\
\hline \multirow{2}{*}{$\begin{array}{l}\text { İşletmenizdeki aile dışı } \\
\text { yöneticiler, işletme } \\
\text { hakkında alınan kararlarda } \\
\text { etkili midir? }\end{array}$} & Evet & 7 & $\begin{array}{l}\text { K5-K11-K12-K13-K14-K15- } \\
\text { K25 }\end{array}$ \\
\hline & Hayır & 18 & $\begin{array}{l}\text { K1-K2-K3-K4-K6-K7-K8-K9- } \\
\text { K10-K16-K17-K18-K19-K20- } \\
\text { K21-K22-K23-K24 }\end{array}$ \\
\hline \multirow{3}{*}{$\begin{array}{l}\text { İşletmenin varsa orta ve } \\
\text { uzun vadede planlarında } \\
\text { aile dışı yöneticilerin } \\
\text { görüşleri alınıyor mu? }\end{array}$} & $\begin{array}{l}\text { Orta vadedeki } \\
\text { planlarda görüş } \\
\text { alınıyor. }\end{array}$ & 14 & $\begin{array}{l}\text { K1-K2-K3-K10-K11-K13-K14- } \\
\text { K17-K18-K19-K20-K21-K22- } \\
\text { K25 }\end{array}$ \\
\hline & $\begin{array}{l}\text { Orta ve uzun vadede } \\
\text { plan yok. }\end{array}$ & 6 & K5-K6-K7-K8-K9-K16 \\
\hline & $\begin{array}{l}\text { Orta ve uzun vadedeki } \\
\text { planlarda görüş } \\
\text { alınmiyor. }\end{array}$ & 5 & K4-K12-K15-K23-K24 \\
\hline $\begin{array}{l}\text { İşletmenizdeki üst kademe } \\
\text { yöneticilerin aile bireyi }\end{array}$ & Evet & 25 & K1----K25 \\
\hline
\end{tabular}




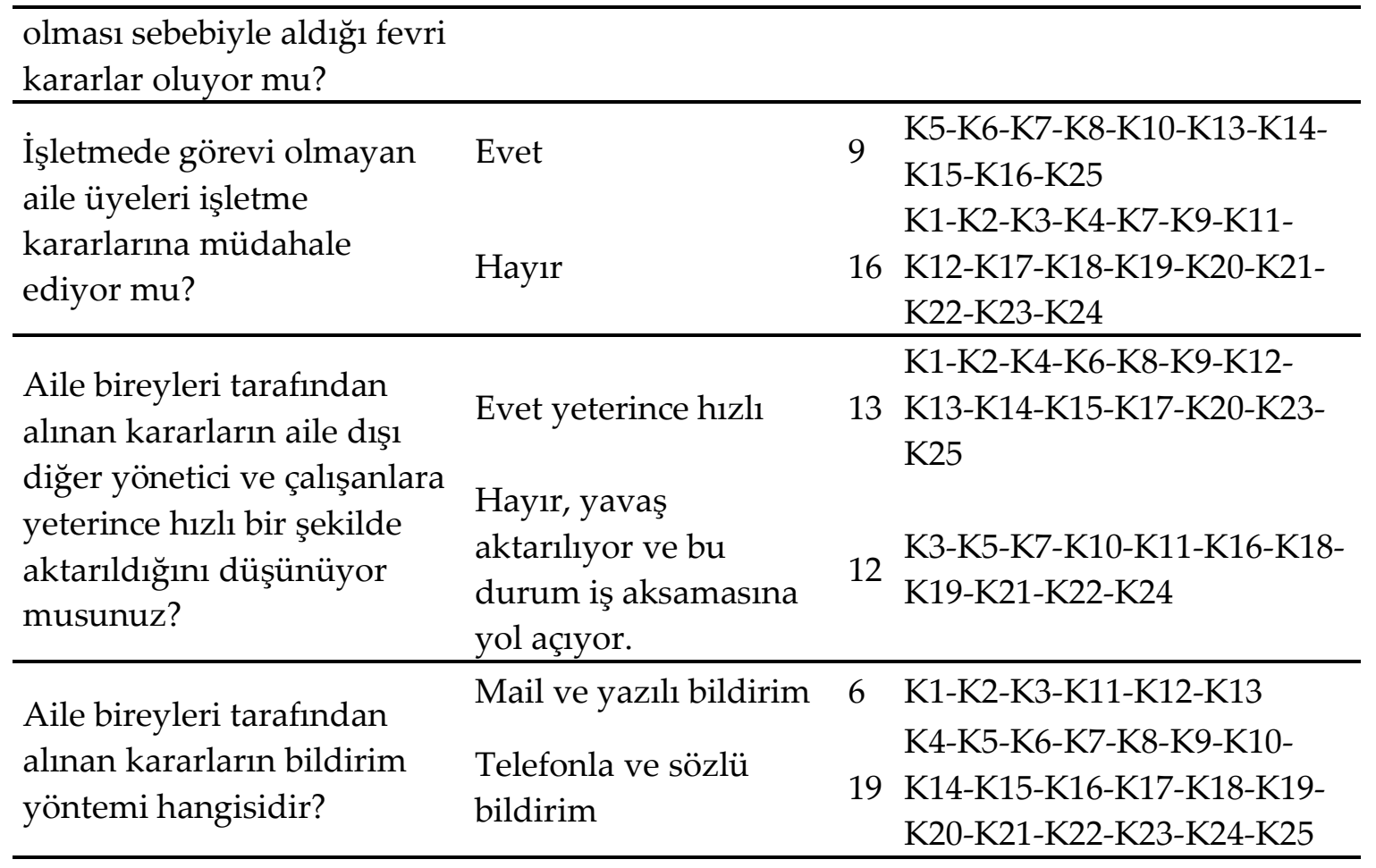

K4 kodlu katılımcıdan farklı bir işletmede çalışan K11 kodlu katılımcının yanıtı aşağıdaki gibidir: 'Orta ve uzun vadede planlarımı elbette var. Orta vadede kâr amacı güden hedeflerimiz olduğu gibi uzun vadede tam olarak kurumsallaşarak kurumsal bir kimliğe sahip olmak, bu şekilde rakiplerimizden bir adım daha ileride olarak sektördeki pazar payımızı arttırmak gibi hedeflerimiz mevcut.' Benzer şekilde kurumsallaşmanın rekabet üstünlüğü için işletmeler tarafından kullanıldığı alanyazında (Gülen, 2005: 21) da yer almaktadır.

"İşletmede stratejik kararları kim almaktadır?" sorusuna katılımcıların \%92'si işletme sahibi yanıtını vermiştir. Benzer şekilde Çelik ve diğerlerinin (2004: 191) çalışmasında aile işletmelerindeki karar almada bütün yetkinin ve karar alma mekanizmasının işletme sahibinin elinde olduğundan bahsedilmektedir. Diğer katılımcılar (\%8) ise işletmedeki stratejik kararların yönetim kurulu tarafından alındığını belirtmiştir.

"İşletmede akraba olmayan yönetici ve çalışanlarn kararlardaki etki oranı nedir?" sorusuna katılımcıların \%60'ı az oranda etkisinin olduğu yanıtını vermiştir. Geri kalan \%40'lık dilim ise akrabalık bağı olmayanların kararlara genelde etki etmediğini belirtmektedir. İşletme sahipleri ile akrabalık bağı olmayan K15 kodlu katılımc1; 'Genelde günlük işler için alınan kararlarda orta derecede etki etmekteyim. Fakat stratejik ve uzun vadedeki kararlarda etki oranım çok azalıyor hatta bazen hiç etki etmemekteyim. Görüşüm hiç alınmıyor.' şeklinde yanıt vermiştir. Aynı şekilde işletme sahipleriyle akrabalık bağı olmayan K2 kodlu katılımcı ise 'Işsletme için önem arz eden kararlarda aile dışındaki hiçbir yöneticiden ve çalışandan fikir alınmıyor. Sadece akrabalık bağı olan yönetici ve çalışanlardan fikir alınıyor fakat çok kritik olmayan basit işlerde kararlarda etkinliğim artıyor." şeklinde yanıtla bu soruya açıklık getirmiştir. Verilen yanıtlardan aile işletmelerinde kararlarda söz sahibi olmada en etkili kriterin akrabalık durumu olduğu söylenebilir.

"İşletme içerisinde aldığınız kararları aile bireylerindeki farklı görüşlerden dolayı uygulamakta zorluk çekiyor musunuz?" sorusunu katılımclların \%72'si 'evet' şeklinde cevaplamıştır. K15 kodlu yiyecek içecek müdürü pozisyonunda bulunan katılımcının yanıtı dikkat çekicidir: 'Her konuda aldığım kararlarda zorluk çekiyorum diyemem. Fakat karşı görüşler 
olmuyor değil ve bu karşı görüşler çalışan personelin yanında dile getirildiği zaman astlarım tarafindan kabul edilebilirliğimi ve gücümü kaybediyorum. Çoğu durumda bana danışmak yerine direkt olarak işletme sahibine veya aileden bir kişiye danışıyorlar.'

"Konu hakkında gerekli bilgisi ve tecrübesi bulunmayan aile bireyleri tarafindan kararlarınıa müdahale ediliyor mu?" sorusuna katılımcların çoğunluğu (\%72) konu hakkında gerekli bilgi ve tecrübesi bulunmayan aile bireyleri tarafından kararlarına müdahale edilmediğini belirtmiştir. 'Hayır' yanıtını veren katılımcıların tamamı bunun sebebinin konu hakkında gerekli bilgi ve tecrübeye sahip aile bireylerinin otorite sahibi olduğunu ve tecrübesiz aile bireylerine yetki vermediğini, işletmenin iç işlerine karışmalarını engellediklerini belirtmişlerdir. Diğer katılımcılar (\%28) ise konu hakkında yeterli tecrübesi ve bilgisi bulunmayan aile bireylerinin kararlarına müdahale ettiğini aktarmaktadır. Bu müdahalelerden dolayı işletme sahibi aile ile akrabalık bağı bulunmayan 3 katılımcı ise aile bireyleriyle tartışma yaşadığını belirtmiştir.

"İşletmenizdeki aile dışı yöneticiler, işletme hakkında alınan kararlarda etkili midir?" K19K20-K21-K22-K23-K24-K25' kodlu aile dış1 yöneticiler işletme hakkında alınan kararlarda hiçbir şekilde etkili olmadıkları şeklinde cevap vermiştir. K1-K2-K3-K4-K6-K7-K8-K9-K10K16-K17-K18 kodlu katılımclar ise işletme hakkında alınan kararlarda etkili olmadıklarını fakat aile bireylerinin kendilerinin düşüncelerine başvurduğunu belirtmiştir. Katılımcıların \%28'i ise 'evet' şeklinde cevap vererek işletme kararlarında etkili olduklarını aktarmıştır. Sektördeki toplam deneyim süresi 20 yıl olan ve 7 yıldır aynı işletmede çalışan K12 kodlu katılımcı bu soruya "Stratejik kararlarda yüzdesel olarak oran verirsem $\% 0$ etki etmekteyim. Ancak idari ve satın alma konularında \%30 etki etmekteyim." şeklinde cevap vermiştir. Bu yanıtla yöneticinin deneyiminin yada işletmedeki çalışma süresinin işletme sahipleri tarafından önemli bir kriter olarak değerlendirilmediği sonucu çıkarılabilir.

"İşletmenin varsa orta ve uzun vadede planlarında aile dışı yöneticilerin görüşleri alınıyor $m u$ ?" sorusuna katılımcıların çoğunluğu orta vadedeki planlarda görüş alındığını belirtmiştir. Toplam deneyim süresi 10 ve 18 yıl olan K1 ve K2 kodlu katılımcılar uzun vadede alınan kararların sadece aile içi görüşmeler ile alındığını aile dışı yöneticilerin sadece bu kararlardan haberdar edildiğini söylemiştir. K4-K12-K15-K23-K24 kodlu katılımcılar ise hem uzun vadede hem de orta vadede alınan kararlarda aile dışı yöneticilerin görüşlerinin alınmadığını bilgisini vermiştir.

"İşletmenizdeki üst kademe yöneticilerin aile bireyi olması sebebiyle aldiğı fevri kararlar oluyor mu?" şeklindeki soruya tüm katılımcılar aile bireyleri olan üst kademe yöneticilerin fevri karar aldığını belirtmiştir. İşletme sahipleri ile akrabalık bağı olmayan ve 16 yıllık sektörel deneyime sahip K25 kodlu katılımc1 “Belirli, oturttuğumuz, bir sistem var. Biz bu sistemi kurmak için günlerimizi, aylarımızı heba ediyoruz. Sistemi nasıl iyileştirebiliriz diye planlar yapıyoruz. Fakat onca emek işletme sahibinin yani aile büyüğ̈̈̈nün aldığg tek bir kararla heba oluyor.' yanıtını vererek durumu özetlemiştir. Yapılan mülakatlarda aile dışı yönetici olan katılımcıların tamamının üst kademe yönetici olan aile bireylerinin aldığı fevri kararlardan rahatsızlık duydukları gözlemlenmiştir.

“İşletmede görevi olmayan aile üyeleri işletme kararlarna müdahale ediyor mu?" sorusuna katılımcıların \%68'i 'hayır' cevabını vermiştir. Evet cevabı veren katılımcılar, işletmede görevi olmayan aile üyelerinin karar mekanizmasında bulunduklarını ve yapılan aile toplantılarında bulunup kararlarının etkili olduğunu belirtmişlerdir. K25 kodlu katılımcı "İşletmede vasfım 
olmasına ve yıllardır tecrübem olmasına rağmen yapılan aile toplantılarına katılamıyorum. Fakat gerekli tecrübesi bulunmayan, işletmede görevi bulunmayan aile bireyleri, aynı soyadını taşıdığı için bu aile toplantılarına katılmaktadır." şeklinde verdiği yanıtla yaşanılan sorunu açıkça aktarmıştır.

"Aile bireyleri tarafından alınan kararların aile dışı diğer yönetici ve çalışanlara yeterince hızlı bir şekilde aktarıldı̆̆ını düşünüyor musunuz?" sorusuna katılımcıların yarısı aile bireyleri tarafından alınan kararların aile dışı diğer yönetici ve çalışanlara yeterince hızlı bir şekilde aktarıldığını düşünmektedir. Hızlı şekilde aktarılmadığını belirten katılımcılar, yavaş aktarımdan dolayı oluşan sorunlardan bahsetmişlerdir. K3 kodlu akrabalık bağı olmayan katılımcının bu konuyla ilgili yaşadıklarını anlattığı aşağıdaki cümleler bilgi paylaşımıyla ilgili durumu açıklamaktadır: 'Bir gün salonumuzda siyasi bir partinin genel başkanının toplantısı vardı. İşletme sahibi anlaşmasını yapmış fakat bize bildirmediği için haberimiz yoktu. Organizasyon saatinden 1 saat önce gazeteden toplantının bizim salonlarımızda olduğunu öğrendim. Acele olarak organizasyon hazırlı̆̆ını yaptık." Aile bireylerinin işletmeyle ilgili aldığı kararların ilgili birim yöneticilerine zamanında ulaştırılmaması işletmedeki işleyişe dolayısıyla da işletme imajına zarar verebilmektedir.

\section{Tartışma, Sonuç ve Öneriler}

Araştırmada aile işletmesi felsefesiyle kurulmuş ve turizm sektöründe faaliyet gösteren işletmelerde farklı bölümlerde yönetici pozisyonunda görev alan katılımcılarla görüşme yapılmıştır. Çalışmada; katılımcıların \%80'inin daha önce kurumsal firmada çalışmaması sebebiyle kurumsallaşma kavramına uzak olduğu dikkat çekmektedir. Ancak yöneltilen sorulara verdikleri yanitlarla aile işletmelerindeki kurumsallaşmayla ilgili genel durum hakkında bilgi sahibi olmaya çalışılmış, yaşanan sorunlar belirlenmeye çalışılmıştır.

Araştırmaya katılan işletme sahibi ile akrabalık bağı olan yöneticiler veya işletme sahipleri kurumsallaşmaya sıcak bakmaktadır. Fakat aile ile akrabalık bağı olan diğer yöneticilerin veya işletme ortaklarının aynı görüşte olmamasından dolayı çatışma yaşadıkları gözlemlenmiştir. Kurumsallaşmaya sıcak bakmayan katılımcılar; gücün elinden gideceğine, müşteri ile bağlantısının kopacağına, aile dışı yöneticilerin işletmeyi kendileri kadar benimsemeyeceğine inanmaktadır. Kurumsallaşmayı destekleyenler ise bunun tam tersini; kurumsallaşmanın işletmeyi büyüteceğini, işleyişin standart hale geleceğini, kendilerinin üzerindeki yüklerin azalacağını düşünmektedir. Yapılan görüşmelerde işletmelerin tümünde ailenin büyügünün işletmede son sözü söyleyen kişi olduğu gözlemlenmiştir. İşletmelerin bir kısmı kurumsallaşmaya çalışan aile işletmelerinden oluşmaktadır. $\mathrm{Bu}$ işletmelerde yönetim kurulunun tam anlamılla işlevini yerine getiremediği gözlemlenmiştir. Yönetim kurulunda aile içi yöneticiler çoğunlukta olup aile dışı yöneticiler azınlıktadır. Alınan kararların hepsinde işletmenin sahibi olan aile büyüğüne danışılmakta olup bazı kararlar doğru olmasına rağmen işletme sahibi tarafından veto edilerek kendi kararının uygulandığı belirtilmiştir.

Aile içi yaşanan sorunların işletmeye yansıması aile işletmelerinin problemlerinden birisidir. Yapılan araştırmada da bu durum gözlenmiştir. Aile dışından olan yöneticiler aile içinde yaşanan problemlerin işletmeye yansımasından şikayetçi olup işlerin işleyişine engel olduğunu belirtmişlerdir. Bu konuda iş ve aile işlerinin birbirinden ayrılması gerekmektedir. İşletmedeki yetki ve sorumluluğun aile dışı yöneticilere verilmesi, işletme sahiplerinin işlerinin başında değil arkasında olması, gündelik işlere değil uzun vadedeki planlara odaklanması hem kurumsallaşma konusunda büyük adım attıracak hem de iş ve aile işlerini birbirinden ayırarak oluşan bu sorunu ortadan kaldıracaktır. 
Aile işletmelerinde yöneticilerin aile bireylerinden şeçilmesi bir çok sorunu ortaya çıarmaktadır. En büyük sorun uygun nitelikte, eğitim seviyesinde ve deneyimde olmayan aile bireyinin kendisi için uygun olmayan konuma getirilmesidir. Bu durum kurumsal olmayan, belli bir kurum kültürü taşımayan işletmelerin varlık göstermesine yol açmaktadır (Yağc1 ve Çevirgen, 2014: 1252). Üst kademe yöneticilerin profesyonel, gerekli eğitimde ve gerekli deneyimde olması aile işletmelerinin kurumsallık açısından atacağı adımları hizlandiracaktır.

Kurumsallaşma kavramı, katılımcıların çoğunluğu tarafından plan ve kararlarda sadece işletme sahibi yada yakınlarının söz sahibi olmaması, bir sistem dahilinde hareket edilmesi olarak anlaşılmaktadır. Katılımcıların \%56'sı işletmelerinin kurumsal kimliğe sahip olmadığını belirtmekle beraber \%92'si aile dışındaki çalışan ve yöneticilerin kurumsallaşma isteğinde olduğunu aktarmıştır.

Aile içinde yaşanan sorunların işletmeye yansıtıldığı düşünen katılımcıların oranı \% 40 'tır. Bu durum işletmeyi orta düzeyde kurumsal olarak nitelendiren $\% 44^{\prime}$ lük dilimin verdiği yanıtla örtüşmektedir. Ortaya çıkan bu benzer sonuçlar, turizm sektöründeki aile işletmelerinde yavaş yavaş kurumsallaşmaya başlandığ1 yönünde yorumlanabilir. İşletmelerin \% 76 'sında orta ve uzun vadede planların varlığı da bu yorumu destekler niteliktedir. Ancak işletmedeki stratejik kararların \%88 oranla işletme sahibi tarafından alınması, kurumsallaşma kavramıyla ilgili bir takım sıkıntıların olduğunu göstermektedir. Elde edilen bulgular ışı̆̆ında turizm sektöründe faaliyet gösteren aile işletmelerinde kurumsallaşma sorunları aşağıdaki gibi siralanabilir:

a. İşletmede üst düzey yönetici pozisyonundaki aile bireylerinin fevri kararlar alması

b. İşletmedeki stratejik kararların bireysel olarak işletme sahibi tarafından alınması

c. Aile bireyleri tarafından alınan kararların sözlü bildirim yöntemi ile iletilmesi

d. İşletmedeki aile dışı yöneticilerin işletme hakkında alınan kararlarda etkisiz olması

e. İşletmede yöneticiler tarafından alınan kararların aile bireylerinin farklı görüşleri nedeniyle uygulamada zorluk yaşanması

f. Aile bireyleri tarafından alınan kararların aile dışındaki yönetici ve çalışanlara hızlı bir şekilde aktarılmaması

g. Aile içinde yaşanan sorunların işletmeye yansıması

Bu çalışmada, turizm sektöründe faaliyet gösteren aile işletmelerinin kurumsallaşma sorunları belirlenmeye çalışılmış olup, bu sorunlara çözüm önerileri sunulmuştur. Bu konuyla ilgili Türkiye genelinde daha geniş bir örneklem ve farklı değişkenler ile nicel bir araştırma yapılması akademisyenlere önerilebilir. Araştırma aile dışı ve aile içi yöneticiler üzerinde gerçekleştirilmiş olup, bu konu hakkında araştırma yapmayı planlayanların aile içi yöneticiler ve aile dışı çalışanları kapsayan bir araştırma yapmasının konuya farklı bir bakış açısı getireceği düşünülmektedir.

\section{Kaynakça}

Akça, N. (2010). Aile İşletmelerinin Tanımı, Özellikleri Ve Aile İşletmelerinde Kurumsallaşma, Denizli İlinde Bir Araştırma. Basılmamış Yüksek Lisans Tezi: Pamukkale Üniversitesi, Denizli.

Aksoy, U. ve Çabuk, A. (2006). KOBİlerde Toplam Kalite Yönetimi Uygulamalarının Kurumsallaşma Üzerindeki Etkileri, Balıkesir Üniversitesi SBE Dergisi, ss: 40-57. 
Akyol, C. ve Zengin, B. (2014). Turizmde Kurumsallaşma Sorunları, Aile İşletmeleri Örneği, Akademik Bakış Dergisi, Sayı: 41, ss: 1-22.

Alkara, M.ve Kiracı, İ. (2009) Aile İşletmelerinde Kurumsallaşmaya Verilen Önem Ve Turizm Sektöründeki Konaklama İşletmeleri Üzerine Bir Araştırma: Alanya-Eskişehir Örneği Afyon Kocatepe Üniversitesi, İ.I.B.F. Dergisi, C:X I,S: I, ss: 167-197.

Aydemir, B., Seymen, A.,O., ve Taşçı, A., (2004) Aile İşletmelerinde Kurumsallaşma Süreci ve Sektörel Bir Uygulama, 1. Aile İşletmeleri Kongresi, Kongre Kitabı, İstanbul Kültür Üniversitesi Yayın,, 17-18 Nisan 2004, İstanbul, ss: 604-617.

Barnes, L.B. and Hershon, S.A., (1976). "Transferring Power in theFamily Business", Harvard Business Review, Vol.54, No.4, ss: 105-114.

Bayer, E. (2005). İşletmelerde Kurumsallaşmanın Sorunsal Hale Gelmesi ve Kurumsallaşamama Nedenlerinin Belirlenmesi, Gazi Üniversitesi İktisadi ve İdari Bilimler Fakültesi Dergisi, 7/3, ss: 125142.

Baykal, A.N. (2004). Mektuplarla Aile Şirketlerinde Kurumsallaşma Babalar, Oğullar Ve Kızlar, Sistem Yayınc1lık:351, 2. Bask1, İstanbul.

Çemberci, M. (2013). Kurumsal Yönetim İlkelerinin Türk Aile İşletmelerinin Yönetim İlkelerine Adaptasyonunun Değerlendirilmesi, Akademik Bakış Dergisi, 34, ss: 1-15.

Doğan S. (1998). İşletmeleri Sürekliliğe Götüren Yol: Kurumsallaşma Ve Önemi, Erciyes Üniversitesi İktisadi ve İdari Bilimler Fakültesi Dergisi,13, ss: 143-168.

Donnelley, R. G. (1964), “The Family Business”, Harvard Business Review, Vol: 42, No:4, ss: 93-105.

Elalmış, S.Ö. (2011). "Aile İşletmelerinde Kuşak Çatışmalarından Kaynaklanan Yönetim Sorunları Bursa İli Örneği", Yayınlanmamış Yüksek Lisans Tezi, Ankara: Atılım Üniversitesi.

Fındıkçı, İ. (2008), Aile Şirketleri, İstanbul: 3.Baskı, Alfa Yayınları.

Goto, T. (2014). Family business anditslongevity, Kindai Management Review, 2, ss: 78-96.

Gülen, D. (2005). Aile İşletmelerinin Kurumsallaşması ve Bu Süreçte Yaşanan Sorunlar: Kahraman Maraş Örneği, Yayınlanmamış Yüksek Lisans Tezi: Kahramanmaraş Sütçü İmam Üniversitesi Sosyal Bilimler Enstitüsü, Kahramanmaraş.

Günel, R. (2005). Aile İşletmelerinde Yönetimin Bir Sonraki Kuşağa Devrinde Karşılaşılan Sorunların Tespitine ve Bu Sorunların Çözümüne İlişkin Bir Araştırma, Yayınlanmamış Yüksek Lisans Tezi, Çukurova Üniversitesi Sosyal Bilimler Enstitüsü İşletme Anabilim Dalı.

Günver, B. A. (2002). Aile İşletmelerinin Yapısı Ve Geleceğgi, İstanbul: İstanbul Kültür Üniversitesi Yayınları, No:18.

Kar, M., Zorkiriş̧̧i E. ve Yıldırım, M. (2004). Turizmin Ekonomiye Katkısı Üzerine Ampirik Bir Değerlendirme, Akdeniz Üniversitesi İktisadi ve İdari Bilimler Fakültesi Dergisi, 4 (8), ss: 87-112.

Karpuzoğlu, E. (2000). Aile İşletmelerinin Kurumsallaşma Düzeylerini Belirlemeye Yönelik Bir Araştırma, Yayınlanmamış Doktora Tezi, İstanbul Üniversitesi Sosyal Bilimler Enstitüsü.

Kırım, A. (2003). Aile Şirketlerinin Yönetimi, İstanbul: Sistem Kitapevi.

Kömeçoğlu, G. (2009). Aile Şirketlerinin Kurumsallaşma Sürecinde Yönetim Kurullarının Yapısı, Yayınlanmamış Yüksek Lisans Tezi: Çanakkale 18 Mart Üniversitesi, Sosyal Bilimler Enstitüsü, İşletme Anabilim Dalı. 
Maxwell, J. (1996). Qualitative Research Design: An Interactive Approach, SAGE Publications, California.

Miller, D., Steier, L., and Miller, I.L.B. (2003). "Lost in Time: Intergenerational Succession, Changeand Failure in Family Business", Journal of Business Venturing, No.18, ss: 513 - 531.

Ozdemir, M. (2010). “Nitel Veri Analizi: Sosyal Bilimlerde Yöntembilim Sorunsalı Uzerine Bir Ç̧alışma", Eskişehir Osmangazi Univiversitesi Sosyal Bilimler Dergisi, Cilt.11, ss: 323-343.

Özkaya M.O., Şengül, C.M., (2006). “Aile Şirketlerinde Kurumsallaşma ve İkinci Kuşağın "Kurumsallaşma" Konusuna Bakış Açısı", D.E.Ü İI..B.F. Dergisi, Cilt.21, Sayı:1, ss: 109-126.

PwC. (2012). Küresel aile şirketleri araştırması 2012 Türkiye sonuçları, İstanbul: PwC Yayınları.

Saral Kobal, K. E. ve Aşkun Yıldırım O. B. (2016). Aile İşletmelerinin Kurumsallaşma Sürecinde İkinci Kuşağın Yaşadığ 1 Sorunlar Üzerine Bir Araştırma, Marmara Üniversitesi Öneri Dergisi, Cilt 12, Say1 46, ss: 97-120.

Sevinç, İ. (2005). “Büyüme Sürecindeki Aile İşletmelerinin Karşılaşabilecekleri Sorunlar: Konya'da Faaliyet Gösteren Aile İşletmelerinde Bir Uygulama", İktisadi ve İdari Bilimler Dergisi, Cilt: 19, Say1: 2, ss: $315-331$.

Tanta, G. (2004). Küçük ve Orta Ölçekli Aile Şirketlerinde Yönetim Fonksiyonlarına İlişkin Sorunlar (Sakarya İli Örneği), Yüksek Lisans Tezi.

Tekin, M. (2004). Girişimcilik ve Küçük İşletme Yöneticiliği, Ankara.

Terzi, H. ve Pata, U.K. (2016). Türkiye'nin İktisadi Büyümesinde Turizm Sektörünün Katkısı, Erciyes Üniversitesi İktisadi ve İdari Bilimler Fakültesi Dergisi, Sayı: 48, ss: 45-64.

Türkiye İstatistik Kurumu (2019). Haber Bülteni, Sayı 30600, Ankara.

Vera, C.F ve Dean. M.A. (2005), “An Examination of the Challenges DaughtersFace in Family Business Succession", Family Business Review, Dec: 18,4; ABI/INFORM Global, ss: 321-345.

Ward, J.L. (1987),"Keeping The Family Business Healthy", San Francisco, CA: Jossey Bass.

Yağcı E. ve Çevirgen A. (20145). Kurumsallaşma Düzeyi ve İşletme Yapısı Arasındaki İlişki: Türkiye'deki Beş Yıldızlı Otel İşletmelerinde Bir Uygulama, 15. Ulusal Turizm Kongresi, ss: 12491264.

Yazıcıoğlu, İ. ve Koç, H. (2009). “Aile İşletmelerinin Kurumsallaşma Düzeylerinin Belirlenmesine Yönelik Karşılaştırmalı Bir Araştırma", Selçuk Üniversitesi Sosyal Bilimler Enstitüsü Dergisi, Sayı: 21, ss: $497-507$.

Yıldız, A. (2008). Aile İşletmelerine Tavsiyeler, Sistem Yayıncılık, İstanbul.

Yolaç, S. ve Doğan E. (2011). “Küreselleşme Sürecinde Aile İşletmelerinde Yönetim ve Kurumsallaşma", İktisat Fakültesi Mecmuası, Cilt: 61, Sayı: 2, ss: 83-110. 